\title{
Why White Instructors Should Explore Their White Racial Identity
}

Stephen D. Brookfield, University of St. Thomas

Why should white instructors in multiracial ABE classrooms explore their own whiteness? If racial identity is largely a cultural, not biological, construct, then why focus on any form of racial markers? Doesn't this constant harping on race create unnecessary divisions and stop us all from getting along? Well, it's not talking about race that disrupts social harmony; it's the fact that whiteness as an identity is connected to power, particularly to the way that a learned blindness to racial inequality helps maintain a system that exhibits structural exclusion and normalizes brutality.

Whiteness buttresses power in a taken for granted, unnoticed way. As George Yancy (2018) writes, this is because racism is not the process of individually demeaning or diminishing others, "a site of individual acts of meanness" (p. 74); rather, it's being "implicated in a complex web of racist power relationships ... heteronomous webs of white practices to which you, as a white, are linked both as a beneficiary and as co-contributor to such practices" (Yancy, 2018, p. 75). Since my whiteness constantly benefits me, and since that benefit accrues to me because we're defined in relation to the supposed "stigma" of blackness, I am racist. I don't go about hurling racial epithets, but I am "embedded in a pre-existing social matrix of white power" (Yancy, 2018, p. 76) that gives me advantages of which I have only an occasional awareness. To feel safe is my norm, to be "systemically racially marked for death" (Yancy, 2018, p. 102) is Yancy's.

I have been struck over the years by the fact that people of color tell me that the most helpful thing whites can do in terms of fighting racism is to become aware of what it means to be white. They say it's much more important for whites to learn that they have a particular racial identity, and to examine how that identity operates in the world, than it is for them to learn about the cultures of racial minorities. Yet in a multiracial classroom, it seems to me that culturally responsive teaching that varies instructional modalities to take account of say, collective modes of generating knowledge, is crucial.

I guess the point of focusing on white identity and white ways of knowing is to stop universalizing white experience as the norm for all humanity. It helps us realize that what appear to us as common-sense approaches to teaching are racially and culturally constructed. For example, the emphasis on individual, not group, assessment reflects the dominance of a Eurocentric paradigm that privileges individualism and selfdetermination as the natural end point of human development. Realizing that individualism is a 
core element of white epistemology helps open us up to more collaborative, group-based forms of assessment. In tribal, indigenous and Afrocentric culture it is the collective that validates knowledge and takes the responsibility for moving knowledge forward.

In trying to engage the fact of whiteness and the reality of a white racial identity we are, of course, engaged in a contradiction. If one of the most cited indicators of white identity is being unable to see that whiteness constitutes a racial marker, then how can a white person possibly become aware of his or her own racial being and think she can teach other whites about it? Don't we need scholars of color to write from a different racial perspective that throws whiteness into sharp relief?

I argue that it's a question of both-and. When people of color highlight elements of whiteness we learn more of how white supremacy operates to circumscribe and devalue lives in a world where whiteness is the norm around which institutions are organized. On the other hand, when whites examine whiteness together, they learn how these norms are transmitted amongst themselves, how challenges to these norms are deflected, and how groupthink operates to stop efforts to identify what whiteness means.

\section{Color Blindness}

A recent anthology on teaching race (Brookfield, 2019) identifies the enduring permanence of the colorblind perspective amongst whites. A colorblind view of the world appeals to many whites for its seeming emphasis on the universal aspect of humanity shared by all people. It is a conscious adoption of Dr. Martin Luther King's dictum that we should judge people not by the color of their skin but by the content of their character. Whites are often very supportive of this view, professing that they take people as they come, give everyone the benefit of the doubt, and then make individual judgments about people that are unaffected by race as they interact with them in particular settings.

Why should color blindness be a problem? Isn't it an anti-racist orientation to say you avoid stereotypes and put biases aside so you can focus instead on the unique humanity of each individual you encounter in your life? Well, if this were truly what was happening, then I would be overjoyed. But the colorblind perspective has two major flaws. First, it implies that whites can indeed quickly put biases aside and see people in an unraced way. Second, it assumes a level playing field is in place in which whites interact with people of color as moral and political equals.

Let's take the issue of being able to detach yourself from a race-based view of the world. My position is that the ideology of white supremacy is so all enveloping that only hermits permanently cut off from all human interaction and all media could escape its influence. So, despite whites saying that they see only people, not color, I don't believe this to be true. To take myself as an example, I have been socialized in a world in which white supremacy underscores how people think and how institutions function. Even though I have spent decades trying to uncover this ideology in myself and to identify racism in the contexts through which I move, I am still held somewhat hostage to my white supremacist conditioning. I hope I get better at detecting its influence and in calling it out when I see it in play. But its frame will never leave me, and I come smack up against it every day of my life.

Now let's think about the fact that racial exchanges don't happen in a flat, neutral terrain. Even if I could remove all biases, stereotypes and 
prejudices from my mental frameworks I would still be moving through an asymmetrical world. Access to jobs, health care and education are so disproportionately advantaged in favor of whites that the "breaking news" cable TV headline that I see every day really should read "revolution still not broken out." There is clear racial segregation in housing and even in "integrated" public schools a color line clearly exists. Incarceration rates for black and brown people are astoundingly disproportionate, and the last few years have highlighted regular shootings of black males by white police. Add to this the demonization of black and brown immigrants as disease-ridden terrorists, rapists, and hardened gang criminals, and it seems impossible for whites not to realize they live in a deeply racist world in which whites are disproportionately advantaged.

When whites say to people of color that they don't see race, they come across as naive in a world where institutions and systems are structured around seeing color and ensuring, in particular, the continued dominance of one racial group. I work for a predominantly white institution that proclaims the worth of every person's dignity, and I'm happy to aspire to that value. But I have also pointed out to those institutions that because of the white supremacy embedded in the way they function, the dignity of institutional members of color can only be enacted if there are radical structural changes in admissions, financial aid, assessment systems, governance, curricula and performance appraisal.

I believe that well-intentioned whites telling students of color that they don't see race, and thinking that means that they can then be trusted, is one of the worst mistakes well-intentioned whites can make. This is because, to most people of color, everything is seen through the lens of race. As a white person you may feel the world is unraced, but you should assume that a person of color sees it in exactly opposite terms. One of the dynamics I've often observed in multiracial conversations is whites saying that they're nonracist and then expecting people of color to take them at their word and to trust them to act accordingly. Personally, I never expect to be trusted by colleagues of color just because I write books, give presentations, and teach courses around racial issues. I always counsel those whites I work with not to get hung up on assessing how much they are trusted by folks of color. I believe they should have as their starting point an expectation of not being trusted. If somewhere down the line a person of color tells you they trust you, then accept that as a recognition of your good work. But don't think you're not being effective if that acknowledgment never comes.

\section{Whiteness Is Not a Racial Identity}

When I ask white people about the moment when they first become aware of their white identity I am often met with bemusement. Equally, the questions 'what does it mean to be white?' or 'what role does your whiteness play in your life?' are viewed almost as nonsensical. This is because many whites don't believe they have a racial identity and that whether or not they are white has absolutely nothing to do with where they are in life, or how they conduct themselves.

The belief that whiteness does not constitute a racial identity is a building block of white normativity; the idea that the norms and standards by which we judge what is acceptable and normal in the world are colored white. And it's something that whites don't usually think about unless, like the white mothers of children of color who must navigate norms of whiteness (Chandler, 2016), something in your experience requires you to do so. Under white normativity 
race is something exhibited only by those with skin not colored white. Whiteness has become viewed as the universal standard, the de-facto center, the common-sense way the universe should look when it's working as normal. Under white supremacy leadership looks white, authority looks white, experts look white and what counts as legitimate knowledge is constructed by whites. The power of white supremacy is that this situation is not understood as being constructed to advantage a dominant racial group. Instead it is viewed as unremarkable, obviously correct, and just the way things are.

If you accept this perspective on life, then race is not something you need to attend to. If being white means you don't have a race, then it's easy to compartmentalize any discussion of race as something appropriate only for people of color. In this way it's quite possible to attend a training on diversity, inclusion or cultural competence, without ever really thinking about what it means to be white. Race is always seen something that others have, and those "others" typically have black, brown, red and yellow skin.

One of the consequences of thinking you don't have a racial identity is concluding that you don't really need to participate in conversations about race, unless you know you're going to be working with people from different racial backgrounds. If you spend your life in predominantly white environments surrounded by people who look like you, then it's not surprising that you'd think that race is something "out there," evident in neighborhoods you don't frequent, streets you don't walk on, and company you don't keep.

\section{Opting In and Out of Race}

Whites who don't believe themselves to be raced and who live mostly in white environments can in effect decide when to opt in or out of thinking about, or dealing with, race. This is a luxury denied people of color who have to navigate a white world for chunks of every day. For me the problem of race is a white problem. White racist structures, policies and practices continue to endure partly because whites don't see how those structures are maintained to disadvantage people of color. The race "problem" is obviously a problem of the systematic marginalization and diminishment of people of color, but it's just as much a problem of how good white people (Sullivan, 2014), who consider themselves to be moved by morality and compassion, don't see how white supremacy keeps racism in place.

Thinking that you can move in and out of dealing with race is a reflection of the individualistic, Horatio Alger mythology so much a part of American culture. It's easy to push thinking about race to the corners of your world if you think that being racist is all a matter of individual choice. Unless you put structural racism at the center of your analysis you can view racism as a matter of personal conduct, of whether or not you have bad thoughts, say bad things, and treat people unfairly.

Thinking that you're a moral, compassionate person and that racism is all a matter of individual choice means that you can think you have an anti-racist identity without doing any collective organizing or cooperation. This is why helping people to think structurally, not individualistically, is so crucial. But in an individualistic culture that routinely celebrates individuals who overcome the odds it's also extremely difficult to foster a whole new way of thinking. To adapt two well-known slogans, a structural perspective holds that the personal is structural and that we should think locally and act structurally. 
If students of color see everything through the lens of race then it behooves a white teacher like myself to explore what it means to experience the world as profoundly racialized. I can't do this by trying to mentally project myself into another person's racial identity. I can't do it by identifying times I've felt excluded and devalued and then trying to link them to experiences of racial marginalization. No, the only way I can experience the world as racialized is by doing a deep dive into my own racial identity and understanding how that benefits me in a racially asymmetrical world. This is why white instructors need to explore their own whiteness.

\section{References}

Brookfield, S.D. and Associates. (2019). Teaching race: Helping students unmask and challenge racism. San Francisco, CA: Jossey-Bass.

Chandler, J.L.S. (2016). Colluding, colliding, and contending with norms of whiteness. Hershey, PA: Information Age Publishing.

Sullivan, S. (2014). Good white people: The problem with middle-class white anti-racism. Albany, NY: SUNY Press.

Yancy, G. (2018). Backlash: What happens when we talk honestly about racism in America. Lanham, MD: Rowman and Littlefield. 